\title{
Can Employee Share Option Scheme Improve Firm's Performance? A Malaysian case study
}

\author{
${ }^{*}$ Choi Sang Long ${ }^{1}$, Mahanra Rao a/l Gondyah², Ajagbe Akintunde Musibau ${ }^{1}$ \\ ${ }^{1}$ Universiti Teknologi Malaysia (UTM), Malaysia \\ 2Wawasan Open University, Malaysia \\ *cslong_1@yahoo.com
}

\begin{abstract}
This paper examines the impact of employee share option schemes (ESOs) on one company in Malaysia. It is hoped that the findings of this study will be useful to companies who wish to adopt such schemes and to market regulators. The financial and operational indicators were studied for a total period of 11 years (five pre-ESOs and five post ESOs). In line with the findings of other studies done in Malaysia, Singapore and other countries, it has been found that the deterioration in financial performance was not arrested by ESOs. The operation and productivity of the company showed no improvement postESOs. This study concludes that ESOs do not motivate employees and the objectives of the ESOs were not fulfilled. This study also finds that the beneficiaries of ESOs are the majority shareholders/managers and the losers are the minority shareholders. Based on these results, it will be difficult to make a case for the usefulness of ESOs.
\end{abstract}

Keywords: Productivity; performance; share option schemes; employees; market; ratio

\section{Introduction}

Firms hire the best managers that they can find to enhance the rewards to the owners and lower the overall risks that they face in a very competitive environment. However, the separation of ownership from management brings with it agency problems of non-alignment with respect to their respective interests. Agency is defined here as a contract between one person, the agent, and another, the owner, committing the agent to perform a service for the owner (Jensen and Meckling, 1976). The owner divests itself of some decision making authority to the agent. The agent in this study includes all the executives of the firm. The interests of management and labour, as factors of production, may not necessarily be aligned to those of the owners. To grapple with this problem, one of the tools that owners of firms have opted for is the employee share option scheme (ESOs). The ESOs are designed to align the interest of the owners with that of the executives. The aim of this alignment is to reduce agency costs and thereby increase the performance of the firm and its market value (Jensen and Meckling, 1976). Shareholders also benefit from increased income in the form of increased dividends when the firm's performance improves. Employee ownership can have a positive effect on a work group's norms, cohesiveness and cooperative behaviours; on an employee's work-related attitudes, motivation, and behaviour; and on an organisation's performance and profitability (Pierce and Furo 1990, cited in Davidson and Worrell, 1994). In Malaysia, the use of ESOs became widespread in the 1990's. In 1989, nine companies adopting ESOs schemes were listed for the first time and this number rose to 41 by the year 2000 . The number of companies adopting ESOs per calendar year varied from 2 to 41 between the years 1989 and 2004 (Ghazali, 2008). The use of ESOs was seen to encourage long term profits by establishing a closer link between the benefits to the firm and the benefits to the individual.

Statement of the Problem: The adoption of ESOs has significant implications for the investing public and the economic development of a country. ESOs, in Malaysia, usually comprise a significant portion of the capital of a company, up to $10 \%$ of the issued share capital. If the objectives of issuing the ESOs are not fulfilled, not only will the interest of the investing public be affected but also the ability of the company to acquire new capital (Ghazali, 2008). Increasing productivity is key issue for government and organisations. Labour plays a major part in any organisation and thus an increase in employee productivity will have a major impact on the overall productivity of the firm. Since the 1980's labour is seen as a key factor in competitive advantage. Therefore, aligning the interests of labour with those of the organisation's goals is considered my many to be crucial for achieving efficient utilization of available resources and the resulting higher productivity (Tai, 2001). There is thus a dire need to establish 
whether the adoption of ESOs does indeed enhance firm performance and productivity and thus indirectly to validate the interest alignment theory. Much of the existing literature on ESOs focuses on US and European stocks and may well be reflective of the environment of those markets. Very little is known, however, about ESOs in developing countries like Malaysia. The findings of past studies have been mixed and so the efficacy of ESOs warrants further research. ESOs are still being issued by listed entities in Malaysia, sometimes more than once. It is our hope that the findings of this study will assist listed entities and their shareholders to better evaluate the effectiveness of ESOs.

The Purpose of the Study: Given the extensive usage of ESOs by Malaysian companies, the use of ESOs and their efficacy as instruments to achieve the purpose of their issuance has yet to be established. This study therefore seeks to contribute to existing literature by exploring the relationship between a specific firm's performance and its issuance of broad based ESOs. In this study, the term performance includes operational performance, financial performance and overall productivity. The objectives of this study are as follows:-

- To investigate whether the objectives of issuing ESOs have been attained, especially with regards to improvement in operational performance;

- To investigate whether financial performance of the firm improves after the grant of ESOs;

- To investigate whether there are productivity gains, post-ESO;

\section{Literature Review}

Previous Studies on Positive Effect of ESOs: Past studies indicate a relationship between the percentage of ESOs outstanding and firm performance. The convergence-of-interest hypothesis dominates before percentage of ESOs outstanding reach $1 \%$ whilst the entrenchment hypothesis dominates above that percentage (Tai, 2001). Tai (2001) infers that the various benefits brought about by ESOs get offset by the costs (a result of the entrenchment effect) of utilising ESOs after the 1\% threshold level. The impact of financial returns on more than a thousand US companies that have adopted ESOs was examined by Conte, Blasi, Kruse and Jampani (1996). They report that adopters have significantly better returns in 8 of the 13 years of their study as compared to non adopters (cited in Obiyathulla et al. 2009) and size too matters. Smaller ESO firms performed better than the peers. Soon (2001) argued that companies with poor operating performance are adopting stock option schemes in the hope of motivating employees to perform better. Soon's studies also supported the notion that firms adopting ESOs are less risk taking and firms which are cash strapped are using it to conserve cash. He concluded that firms adopting ESOs are performing better than their peers by encouraging risk taking behaviour and conserving cash. Sengupta et al. (2007) found a positive correlation between share ownership and low labour turnover. They conclude that ESO schemes improve organisational performance through reduced employee turnover by helping the firm to economise on hiring/firing costs and protect valuable investment in specific human capital and hence enhance performance. Agrawal and Knoeber (1996) examined the use of seven mechanisms to alleviate the agency problems between managers and shareholders. These are the use of debt (lenders evaluate a managers performance), the labour market for managers (poor performing managers can be replaced), market for corporate control (reliance placed on prospective acquirers), shareholdings of insiders, institutions, large block holders and outside directors. Their findings were that greater outside representation on the board of directors, more debt financing and more corporate control activity all lead to poorer firm performance. Greater insider shareholdings lead to better firm performance, although the authors argue that the results could also be interpreted the other way, i.e., better firm performance may lead to greater insider shareholdings, fewer outsiders on the board, less debt and fewer takeovers.

Sesil and Maya (2005) examined labor productivity, operational efficiency (return on assets), financial performance (profit margin), and total shareholder return (TSR) in broad-based stock option firms across small to large sized firms. A broad based stock option firm is one in which more than $50 \%$ of nonmanagement employees actually receive stock options. They found that ESO adopters perform better than non adopters across all size categories. Their results can be summarised as follows:

- Small stock option companies have higher productivity compared to large stock option companies, and the difference is statistically significant.

- Return on assets and profit margins too show a similar trend as productivity. Small stock option firms have higher returns than large stock option firms but the difference is not statistically significant. 
One of the latest study conducted on British firms, on the effects of stock ownership, complemented by employee involvement (Pendleton and Anderw, 2010) found that stock plans have independent effects on productivity, despite the free- rider theory. They even found instances when employee participation in decision making has negative impact on productivity. Pendleton and Andrew (2010) went on to say that their findings were consistent with the widespread view that it encourages employee retention.

Previous Studies on Non Effective ESOs: Davidson and Worrel (1994) found that there was no improvement in firms' operational performance for two years after an ESO. In the sample of firms selected by them, financial performance has deteriorated in the second year following ESO implementation. However, they did qualify their statement that it is not possible to show that the drop in performance, relative to industry, is actually caused by the issue of ESOs and that the results may not apply to all ESOs. Financial performance was measured using four ratios: ROA (Return of Assets), NAL (Net Profit Margin), Asset Turnover and Debt-to-Asset. Productivity, as measured by asset turnover ratios had large increases, especially in the first year following ESO. In explaining the contradiction between the positive market reaction and lack of financial improvement, the authors propose two possibilities: first, that an ESOP announcement could signal takeover defence; and second, that it could signal that managers believe the firm is undervalued and will offer cheap stock as a reward to employees. $\mathrm{Ng}$ (1999) found that although there is a significant stock market reaction to ESOs adoption, lending support to the alignment of interest theory, the operating performance declines slightly after. Yeo et al. (1999) examined the operating performance of 54 firms listed on the Stock Exchange of Singapore for a three year period before and after the ESOP announcement. The performance measures used were operating income before depreciation, interest and taxes (OIBD) divided by total assets, OIBD divided by total sales, net income divided by total assets and net income divided by total sales. The researchers found that there is no significant improvement in the operating performance following adoption of ESOs. They conclude that the regulatory restrictions and fiscal disincentive in Singapore led to the ineffectiveness of ESOPs in enhancing shareholder wealth and firm performance.

Sengupta et al (2007) in their analysis of their study of found that ESO adoption does not lead to higher levels of commitment although firm performance improves through lower labour turnover. In a study of 52 Malaysian companies (26 ESO firms and their matched industry peers) over a period of 12 years, Obiyathulla et al (2009) found that operating performance deteriorates for ESO companies. Profitability as defined by the net profit margin, return on assets and return on equity all declined, the biggest drop being in the immediate one-year period following ESO announcement. The size of the firms matter too. While the net profit margin was little changed post ESO for large firms, small firms experienced a substantial fall in net profit margin post ESO. However, efficiency ratios as defined by the total assets turnover, fixed assets turnover, days sales outstanding and inventory turnover showed improvements post ESO. The researchers opine that the reason for the large drop in operating performance for small firms could be due to management appropriating more benefits to themselves at the expense of external shareholders, i.e., agency problems may have worsened for small firms. They conclude their study by saying that employees obviously gain and shareholders lose when ESOs are issued and that shareholders of smaller firms lose even more than those of large firms. The rationale and objectives of issuing ESOs are thus not fulfilled. Meng, et al. (2010) compared the performance between ESOP firms and non-ESOP firms and the measures used were return on assets (ROA), return on equity (ROE), Tobin's q and productivity. Their findings were that ESOP firms did not perform differently from non-ESOP firms for each of the performance measures. They conclude that the highly diffused equity ownership among employees results in the free-rider problem and thus does not meaningfully affect employee incentive and corporate performance. In a study of 202 Indian companies listed on the Bombay Stock Exchange, Dhiman (2008) found that ESOP does not improve the productivity performance in the Indian corporate sector in the short run. The study was based on pre- and post adoption period of one year and 3 years respectively covering a wide range of industry grouping. The asset turnover ratio (ATO), net sales/net assets at book value, was used as the productivity measure. Out of the 202 companies chosen, 103 adopted ESOP.

\section{Research Methodology}

The Company Selected for this Study: The actual name of the company chosen for this case study is withheld. This company in this paper will be called as A Limited (AL). The principal activities of AL are the manufacture and marketing of aluminium products on a global basis. AL's group's production capabilities (AL, 2008), include an aluminium re-melt capacity of 200,000 metric tons per annum and an extrusion capacity of 160,000 metric tons per annum. AL started as a privately owned local aluminium 
extrusion company in 1986 and was listed on KLSE Malaysia in August of 1993. It has four business segments; Manufacturing \& Trading, Contracting \& Fabrication, Property Development and Recycling \& Waste Treatment. The products produced by $\mathrm{AL}$ are for the building and construction industry, transportation, electronics and semi-conductors, and consumer segments. AL's ESOs, the subject of this study, was approved by the Securities Commission on 8th September 2000, (Bursa Malaysia Berhad 2011) and was implemented on 6 June 2002. It was proposed that up to $10 \%$ of the existing share capital be issued to eligible employees and executive directors of the AL Group. Pursuant to the Employee Share Option Scheme, options to subscribe for up to 6,201,556 ordinary shares of the Company were made available to eligible employees and directors of the Group. Out of the total number offered, 2,700,000 ordinary shares or $43.5 \%$ were offered to the directors of the AL Group. These ESOs expired on 5 June 2007.

Data Collection:_The data for the study has been obtained from the published annual reports and audited financial statements of the companies chosen and hence may be regarded as reliable. At our request, AL provided us with annual reports for the 11 years under study. Data on the number of options exercised by the firm per financial year, within the period of study, has been obtained from the Director's Report, which is included as part of the audited financial statements.

Variables: The two primary categories used to study operational performance and financial performance is the asset utilization ratios and profitability ratios (Block \& Hirt 2008). A ratio is the quotient of a number or a sum divided by another numerical figure. The ratio concisely shows the relationships among the selected financial data contained in financial statements. These ratios are useful in analysing relative performance for between different firms or different periods in the same firm.

The data relevant to operational performance (asset utilization ratios) is as follows:

- Trade receivables turnover;

- Inventory turnover;

- Free cash flow to equity (FCFE) per share.

Data relevant to financial performance (profitability ratios) is:

- Return on assets (ROA)

- Return on equity (ROE)

- Net profit before taxation (NPBT)

- $\quad$ Net profit after taxation (NPAT)

Data relating to productivity, is the asset turnover ratio (Dhiman, 2009), which is defined as net sales/net assets. Net sales are defined as sales less returns and discounts. Net assets are defined as fixed assets (excluding outside investment) plus current assets. Revaluation surpluses arising from a revaluation of fixed assets are excluded. The fixed assets are stated as cost less accumulated depreciation or amortization.

\section{Explanation of Asset Utilization Ratios}

- The trade receivable turnover specifies how many times per year a company collects its accounts receivable. Accounts receivable refers to the debt created when a sale is made on credit. The trade receivables turnover is computed by dividing net sales by the average trade receivables. The term average trade receivables refer to the average of the amounts at the beginning and end of the financial year. If ESOs improve operating performance, then the turnover will be higher, i.e., the collection period will be shorter.

- The inventory (or stock) turnover ratio shows the speed at which the firm is turning over inventory. It is computed by dividing the net sales by the average inventory. Average inventory is the average of the amounts at the beginning and end of a financial year. When ESOs improve operating performance, then the turnover or the number of times per year inventory is sold or used is larger.

- Free cash flow to equity (FCFE) per share at issue is computed by deducting cash flow from investments (CFI) from cash flow from operations (CFO) plus net borrowings (NB) and dividing the resultant figure by the average number of shares issued during the financial year (Investopedia ULC, 2011). If there is a share split during any of the years being researched, the number of shares is taken at the initial par value for consistency. The CFO, CFI and NB will be 
obtained from the Statement of Cash Flows that is included in the financial statements. Onetime cash flows that do not arise from normal activities will be removed from the total cash flows to reflect sustainable cash flows. An increased ratio will mean an improvement in the operating performance.

\section{Explanation of Profitability Ratios}

- The return on assets (ROA) provides an overall measure of how well the firm generates profits relative to the size of its asset base. The Du Pont system of analysis, which uses the profit margin multiplied by the asset turnover, will be used here. The asset turnover, also a measure of productivity in this study, is the ratio of net sales to total net assets. The profit margin is the ratio of net profit before taxes to net sales. In this case study, tax expense is considered to be an appropriation of profits and not an expense because comparability of data would be affected by the permanent timing of differences arising from tax incentives. The Du Pont system of analysis indicates which factor drives the changes in ROA, the profit margin and the asset turnover (productivity). Generally, an overall increase in the ROA as compared to the previous year means that the company is more profitable.

- The return on equity (ROE) is the ratio of the net income available to shareholders, after deducting minority interests

- And the equity. Equity, also known as shareholders funds, is defined as the issued share capital plus retained earnings and other reserves, but excludes revaluation reserves. The average of the shareholders fund at the beginning of the financial year and at the end will be used as the denominator. An increase in the ROE, when compared to the previous year, will mean that more income is available for distribution to the shareholders.

- The net profit before taxes (NPBT) margin is the ratio of the net profit before deducting tax expense and net sales. This ratio shows how much profit is made per ringgit of sales. Tax expense can be reduced by better tax planning and will be affected by capital expenditures and incentives that may not be a regular item in all the years under study. The higher the profit margin before taxes, the better the company's performance.

- The net profit after taxes (NPAT) margin is the ratio of the net profit after deducting the tax expenses and net sales. This is quite similar to the net profit before taxes margin with a higher margin indicating better performance.

To measure a company's pre- and post-ESO profitability and productivity, we define the year that the ESO is created as year $t$ (Davidson and Worrel 1994). We then compare the ratios in years $t-1, t-2, t-3, t-4$ and $t-5$ with the years $t+1, t+2, t+3, t+4$ and $t+5$. The period of 5 years is chosen because it takes time to implement new strategies and efficiency improvements, and more so than not, the effects will only be seen after the second year. The mean of each ratio in the pre-ESO period is then compared to the mean of the ratio in the post-ESO period. If ESOs do indeed improve profitability and productivity, then the change in the ratios must be not less than $20 \%$. If the results are below this, then they would be inconclusive.

\section{Results}

Operational Performance: The indicators of the operational performance for the 11 years under study are as follows.

Table 1: Operational Performance Ratios for AL

\begin{tabular}{|c|c|c|c|c|c|c|c|c|c|c|c|}
\hline Year & $\begin{array}{l}t-5 \\
1997 \\
\end{array}$ & $t-4$ & $t-3$ & $t-2$ & $t-1$ & $\begin{array}{l}t \\
2002 \\
\end{array}$ & $t+1$ & $t+2$ & $t+3$ & $t+4$ & $\begin{array}{l}t+5 \\
2007 \\
\end{array}$ \\
\hline $\begin{array}{l}\text { Receivables } \\
\text { Turnover }\end{array}$ & 3.1 & 3.0 & 3.2 & 2.9 & 2.2 & 2.4 & 3.0 & 2.8 & 3.1 & 3.8 & 5.2 \\
\hline$\%$ change & & $(4.0)$ & 6.1 & $(9.3)$ & $(24.0)$ & 11.4 & 23.9 & $(9.9)$ & 16.4 & 19.3 & 39.2 \\
\hline $\begin{array}{l}\text { Inventory } \\
\text { turnover }\end{array}$ & 12.0 & 10.0 & 10.8 & 12.3 & 11.9 & 10.7 & 10.6 & 6.2 & 5.2 & 5.3 & 6.5 \\
\hline$\%$ change & & $(16.9)$ & 6.7 & 15.4 & $(3.8)$ & $(9.8)$ & $(0.7)$ & $(41.9)$ & $(16.6)$ & 2.6 & 22.1 \\
\hline $\begin{array}{l}\text { FCFE } \\
\text { (RM/1,000 } \\
\text { shares) }\end{array}$ & $(500)$ & 5 & $(413)$ & $(663)$ & 31 & 30 & 138 & 116 & (182) & 201 & 315 \\
\hline
\end{tabular}


Table 2: Debt/Equity ratio for AL

\begin{tabular}{llllllllllll}
\hline Year & $\begin{array}{l}\mathbf{t}-\mathbf{5} \\
(\mathbf{1 9 9 7 )}\end{array}$ & $\mathbf{t}-\mathbf{4}$ & $\mathbf{t}-\mathbf{3}$ & $\mathbf{t}-\mathbf{2}$ & $\mathbf{t}-\mathbf{1}$ & $\begin{array}{l}\mathbf{T} \\
\mathbf{( 2 0 0 2 )}\end{array}$ & $\mathbf{t + 1}$ & $\mathbf{t + 2}$ & $\mathbf{t + 3}$ & $\mathbf{t + 4}$ & $\begin{array}{l}\mathbf{t}+\mathbf{5} \\
(\mathbf{2 0 0 7 )}\end{array}$ \\
\hline $\mathrm{D} / \mathrm{E}$ & 1.09 & 1.01 & 1.11 & 1.19 & 1.15 & 1.24 & 1.00 & 1.12 & 0.82 & 1.85 & 1.86 \\
\hline
\end{tabular}

Figure 1: Trade receivables and Inventory turnovers for AL.

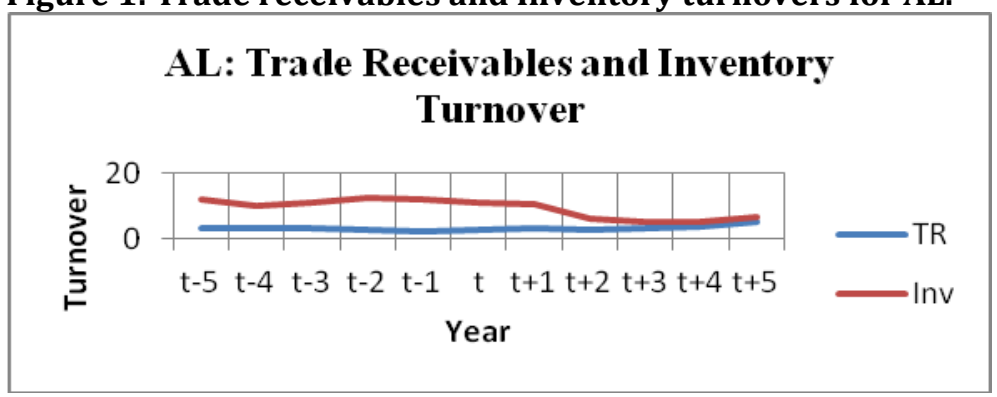

Figure 2: Operational Performance - FCFE/1,000 shares for AL.

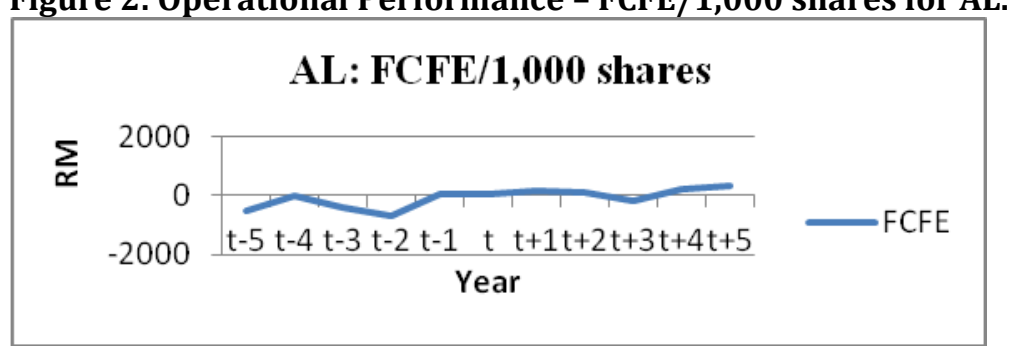

The year $t$, the base year (2002), is the year in which the ESOs became effective. Table 1 shows the three factors that have been chosen to study the operational efficiency. Figure 1 shows the trade receivables and inventory turnover whilst Figure 2 shows the free cash flow to equity in graphical terms. The trade receivables turnover was deteriorating in the five years before ESOs was issued and improved gradually post- ESOs. In the financial year ending 31 December 2007, the trade receivables turnover rate was $115.6 \%$ of the base year. The turnover showed significant improvement only in the fifth year, post- ESOs, which is the year in which most of the ESOs were exercised. This indicates that the impact of ESOs can only be seen after the employees and directors have committed their money to the venture. The higher turnover rate means that $\mathrm{AL}$ is able to collect its debts faster and hence improving cash flow and liquidity. However, the inventory turnover rate has decreased post ESOs indicating a deteriorating management of inventory and hence leading to higher holding costs. AL has expanded rapidly overseas, especially in China, and in the financial year 2007 the smelting operations of its China subsidiary was incorporated into the results for that year, nearly doubling the group's turnover as compared to the financial year 2006. This rapid expansion could be one of the reasons for the deterioration of inventory management as $\mathrm{AL}$ is entering a new learning curve with respect to the smelting operations and being overseas. The inventory turnover curve is showing an improvement after $2006(t+4)$, rising from 5.28 to 6.45 in the financial year 2007. This trend is also in line with the trend in the trade receivables turnover which further reinforces the view that significant improvements can be seen after the share options were exercised. A study of the results for the following financial years could confirm the trend.

Figure 2 shows the trend in the free cash flow to equity (FCFE), which is the amount of cash that is available for distribution to shareholders. From a negative cash flow of RM663 per 1,000 ordinary shares in the year $2000(t-2)$, the FCFE as risen to a positive RM315 in the year $2007(t+5)$. There has been a steady rise in the FCFE since the base year 2002, except for a dip in the year $2005(t+3)$. This rise could be partly due to the increased level of borrowings in the years 2006 and 2007 as indicated by the high debt/equity ratio of 1.85 and 1.86 respectively. In the financial year 2005, the dip in the FCFE to a negative value is due to the substantial investment in property, plant and equivalent (AL purchased a property in China) and repayment of debts from internal resources. The company has been expanding every year by investing in its productive capacity. The higher rate of trade receivables turnover in the financial years 2006 and 2007 are also contributing factors to the higher FCFE in those years. Generally, all three performance indicators showed significant improvements in the fifth financial year post-ESOs, the year in which most of the share options were exercised. There was a general deterioration in the performance indicators in the pre-ESOs period. 
Financial Performance and Productivity: The financial performance indicators for the 11 years are as follows.

Table 3: Financial performance indicators

\begin{tabular}{|c|c|c|c|c|c|c|c|c|c|c|c|}
\hline Year & $t-5$ & $t-4$ & $t-3$ & $t-2$ & $t-1$ & $\mathbf{t}$ & $t+1$ & $t+2$ & $t+3$ & $t+4$ & $t+5$ \\
\hline NPBT (\%) & 11.83 & 4.93 & 5.53 & 6.69 & 4.21 & $\begin{array}{l}5.9 \\
5\end{array}$ & 5.15 & 2.67 & 2.68 & $\begin{array}{l}3.9 \\
5\end{array}$ & 7.83 \\
\hline NPAT (\%) & 9.39 & 4.06 & 5.77 & 5.28 & 3.26 & $\begin{array}{l}4.3 \\
8\end{array}$ & 3.69 & 2.41 & 2.78 & $\begin{array}{l}3.0 \\
2\end{array}$ & 7.65 \\
\hline ROA (\%) & 10.23 & 4.31 & 4.59 & 6.15 & 3.63 & $\begin{array}{l}5.6 \\
7\end{array}$ & 6.40 & 2.66 & 2.55 & $\begin{array}{l}3.6 \\
3\end{array}$ & 6.60 \\
\hline ROE (\%) & 22.58 & 8.63 & 11.17 & 10.86 & 5.74 & $\begin{array}{l}7.8 \\
7\end{array}$ & 11.26 & 7.17 & 6.94 & $\begin{array}{l}9.0 \\
8\end{array}$ & 36.85 \\
\hline
\end{tabular}

The trend in productivity is shown in Table 4.

Table 4: Trend in productivity

\begin{tabular}{llllllllllll}
\hline Year & $\mathbf{t}-\mathbf{5}$ & $\mathbf{t}-\mathbf{4}$ & $\mathbf{t}-\mathbf{3}$ & $\mathbf{t}-\mathbf{2}$ & $\mathbf{t}-\mathbf{1}$ & $\mathbf{t}$ & $\mathbf{t + 1}$ & $\mathbf{t + 2}$ & $\mathbf{t + 3}$ & $\mathbf{t + 4}$ & $\mathbf{t + 5}$ \\
\hline Productivity & 0.86 & 0.88 & 0.83 & 0.92 & 0.86 & 0.95 & 1.24 & 1.00 & 0.95 & 0.92 & 0.84 \\
\hline
\end{tabular}

The graphical representation of the financial indicators and the productivity ratio is shown in Figure 3. Figure 4 shows the trend in the return on assets and return on equity.

Figure 3: Graph showing trends in the financial ratios for AL.

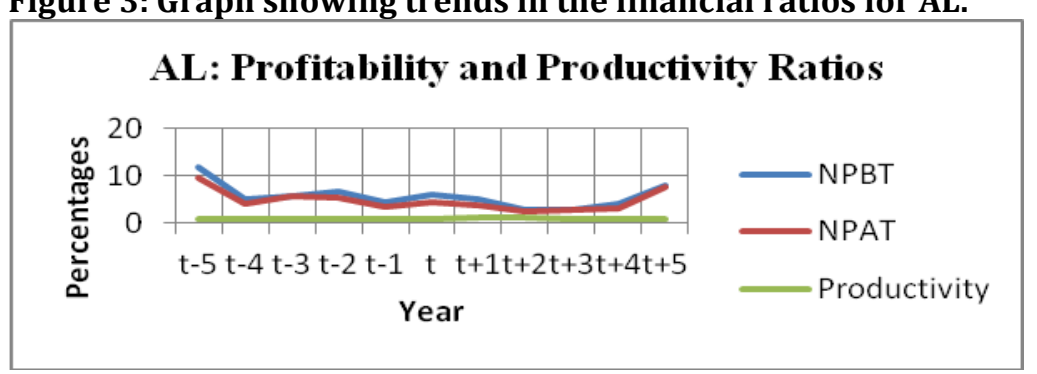

Figure 4: Trend of Return on Assets and Return on Equity for AL.

\section{AL: Return on Assets (ROA) and Return on Equity (ROE)}

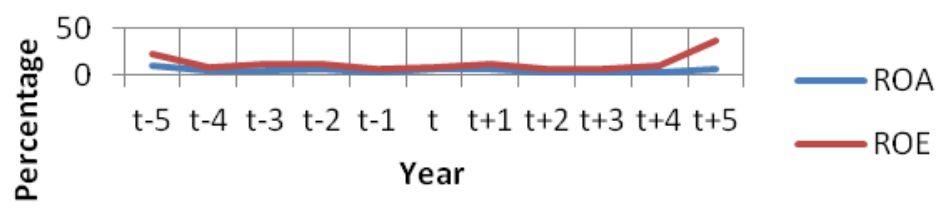

The net profit before tax margin declined sharply from the year t-5 and averaged about 5.34\% in the 4 years before the adoption of ESOs. Post ESOs, the net profit before tax margin (NPBT) declined sharply after the first year and averaged only $2.68 \%$ in the second $(t+2)$ and third years $(t+3)$. Financial performance picked up steam in the fourth year, $(t+4)$ and the fifth year $(t+5)$, with NPBT rising by $47.6 \%$ and $98.1 \%$ respectively. The rise could be attributed largely to the smelting operations in China. Both the ROA and ROE declined sharply from the $\mathrm{t}-5^{\text {th }}$ year and reached the lowest level of 3.63\% (ROA) and $5.74 \%$ (ROE) in the year immediately before ESOs. The ROA improved by $55.9 \%$ in the year $\mathrm{t}$ and $12.9 \%$ in the year immediately after ESOs but declined in the $t+2$ and $t+3$ years to hit the bottom for all eleven years of the study. An analysis of the components of ROA shows that the driver for its improvement in the two years $t$ and $t+1$ is productivity. The significant reduction in the NPBT in the $t+1$ and $t+2$ years negated productivity improvements and hence the lower ROA. The ROA showed significant improvement in the $t+5$ year, rising by $81.7 \%$, due mainly to the increase in NPBT. The ROE showed a similar trend as the ROA but improved sharply in the $t+5$ year to hit an all time high of $36.85 \%$, a rise of $305.8 \%$ over $t+4$. The increase in the $t+5$ year could be attributed to the smelting operations in China. Productivity ratios 
were however quite flat throughout the eleven years of the study, ranging from 0.83 to 1.24 . Interestingly, productivity was highest in the immediately post ESOs year, $\mathrm{t}+1$ and declined in subsequent financial years. ROA and ROE showed significant improvements in the $t+4$ and $t+5$ years. Productivity however showed declines in all of the years $t+2$ to $t+5$. The drop was $32.3 \%$. It could be said that ESOs would only have an impact if the options have been exercised, then the productivity trend should be correlated to the timing of the exercise of the options.

Discussion: The ESOs schemes adopted by AL have not been effective with respect to the reasons for which they were adopted. The results support the free rider economic theory, which postulates that the weak connection between individual effort and reward is a disincentive. The results are in line with those of Davidson and Worrel (1994), Obiyathulla et al (2009), Meng, et al. (2010), Dhiman (2008) and closer to home, Yeo et al. (1999). The results are comparable to the findings of Obiyathulla et al. (2009), which are more relevant in our study because they are also based on Malaysian listed companies. In line with Obiyathulla et al. (2009), the financial performance deteriorated most in the year following issuance of ESOs. Davidson and Worrell (1994) found that average financial performance decreased in the second year after the initiation of ESOs and large increases in asset turnover ratios (productivity) in the first year. In this study, financial performance decreased in the first year after the initiation of ESOs and productivity gains were in line with the findings of Davidson and Worrell. Yeo et al. (1999) found no significant improvement in the operating performance of Singapore listed companies following adoption of ESOs, thus corroborating the findings in this study. AL adopted ESOs when its financial performance was deteriorating. The net profit before taxes (NPBT) deteriorated by $64.4 \%$ between the years $\mathrm{t}-5$ and $\mathrm{t}-$ 1. It is thus safe to conclude that ESOs were introduced in an effort to arrest the deterioration in the NPBT, although there might be other reasons for the deterioration, such as increased competition in the industry. That the introduction of ESOs did not bear fruit can be explained as follows. Executive directors have the right to exercise all their shares within the first year, whereas middle management and lower level of employees can only exercise $30 \%$ of the offered shares in the first year and are only eligible to exercise them by $100 \%$ after the third year. This is obviously discriminatory and may be perceived as such by the lower level employees and thereby might well be a de-motivating factor. This is supported by the high level of lapses by employees who do not exercise their options. The discount offered on the options is only $10 \%$ off the market value. If taxation of the gains is taken into account, it is quite obvious that the rewards are too little to be a significant motivating factor.

The main reasons advanced by AL for the adoption of ESOs are to motivate employees to achieve superior performance, retain employees and to instil a sense of loyalty among them. Other reasons advanced are to reward the employees, create a sense of belonging to the firm and to attract prospective executives to fill key positions. Have these objectives been achieved? The findings indicate that none of the objectives have been fulfilled. The financial performance indicators have deteriorated post-ESOs. Productivity ratios have not shown any significant improvement. It is unlikely that the employees of AL would view themselves as being rewarded. This is because the discount rate is a miserable $10 \%$ from the market value and part of this gain would be lost to taxes. The high level of lapsed offers, $20.5 \%$, is indicative that the employees (apart from the directors) do not view the ESOs as rewards. It is noted that only the directors of AL exercised their rights fully. The high level of lapsed offers seems to indicate that the employees have either left the firms or they do not find the ESOs offer attractive. Therefore it is reasonable to conclude that the ESOs scheme has not achieved its objective of retaining employees or increasing the level of loyalty. Perhaps as McCarthy (2010) said the failure could be due to a lack of "creating a line of sight between employee performance and reward".

\section{Conclusion}

Implications: The ESOs might be improved by taking the following measures.

- Offer a bigger discount on the market value, so that the gains to employees, after taking into account tax expenses, would be more appealing.

- Executive directors who are also majority shareholders might not be offered share options.

- Lower level employees might be offered more shares compared to senior managers.

- The offer of shares might be timed to coincide with lower market prices so that the upside potential for gains would be considerable. 
Blasi and Kruse (1991) note that if employee ownership has a viable future in public companies, it must demonstrate that its social, political, and personal benefits to workers translate into financial benefits for all public shareholders or, at the least, do not injure the financial interests of all shareholders.

Suggestions for Future Research: One major limitation of this study is that it only focuses on one company listed on the KLSE Malaysia. The findings thus may not be representative of all companies who adopt ESOs, although they are in line with other studies done in Malaysia and elsewhere. The present study was based purely on the analysis of the financial statements of the company over an 11 year period. A more personalized approach to the study might be undertaken by conducting interviews to ascertain the perception of employees who are the intended recipients of the share options, especially the lower level employees. Such a study could throw light on the effectiveness and usefulness of ESOs in furthering the interests of all stakeholders, including the minority shareholders. Another focus of the impact of ESOs could be on companies from different industries and sectors. A comparative study might be done in future base on difference industries or firm size.

Acknowledgement: Authors wish to acknowledge the Research Management Centre of Universiti Teknologi Malaysia under the Research Grant (Vot. 4P064) for supporting and sponsoring this publication.

\section{References}

Agrawal, A. \& Knoeber, C. R. (1996). Firm Performance and Mechanisms to Control Agency Problems between Managers and Shareholders. Journal of Financial and Quantitative Analysis, 3, 377-397.

AL. (2008). Financial Statement. Kuala Lumpur: Press Metal Berhad. Retrieved 18 September 2011 from http://www.pressmetal.com.

Block, S. B. \& Hirt, G. A. (2008). Foundations of Financial Management, $12^{\text {th }}$ Edition, New York: McGrawHill/Irwin.

Brickley, J. A., Bhagat, S. \& Lease, R. C. (1985). The impact of long-range managerial compensation plans on shareholder wealth. Journal of Accounting and Economics, 7, 115-129.

Bursa Malaysia Berhad. (2011). General Announcement No MM-000908-51358; issued by Bumiputra Merchant Bankers Berhad on 8.9.2000. Retrieved 31 July 2011 from http://www.bursamalaysia.com/website/bm/listed_companies/company_announcements/anno uncements/archives.jsp.

Davidson, W. N. \& Worrell, D. L. (1994). ESOPS's fables: The influence of employee stock ownership plans on corporate stock prices and subsequent operating performance. Human Resource Planning December 1994. Retrieved 29 July 2011 from http://www.entrepreneur.com/trade journals/article/print/16952455.html .

Demsetz, H. (1983). The structure of ownership and the theory of the firm. Journal of Law and Economics 2(2), 375-390.

Dhiman, R. K. (2009). The elusive stock option plan-productivity link: evidence from India. International Journal of Productivity and Performance Management, 58(6), 542-563.

Ghazali, Z. (2008). The use of ESOS as Interest Alignment Mechanism in Malaysia: A Mismatched of a Problem and Solutions. Academic Exercise, Universiti Sains Malaysia. Retrieved 20 July 2011 fromhttp://eprints.usm.my/10402/1/THE_USE_OF_ESOS_AS_INTEREST_ALIGNMENT_MECHANI SM_IN_MALAYSIA.pdf.

Haugen, R. A. \& Lemma, W. S. (1981). Resolving the agency problems of external capital through options. Journal of Finance, 36, 629-648.

Investopedia, U. L. C. (2011). Advanced financial statement analysis. Retrieved 30 July 2011 fromhttp://www.investopedia.com/inv/pdf/tutorials/financialstatements.pdf.

Jensen, M. \& Meckling, W. (1976). Theory of the firm: Managerial behaviour, agency costs and ownership structure. Journal of Financial Economics, 3(4), 305-360.

Meng, R., Zhou, X. \& Zhu, H. (2010). Do ESOP's enhance firm performance? Evidence from China's reform experiment. Journal of Banking and Finance. Retrieved 5 July 2011 from. Doi 10.1016/j.jbankfin.2010.11.004.

Ng, W. C. (1999). The Impact of Employees' Share Option Schemes in Singapore. Academic Exercise. University of Singapore.

Obiyathulla, I. B, Sharifah-Raihan, S. M. Z., Mohd-Eskandar, S. M. R \& Azhar, M. (2009). Granting Employee Stock Options (ESOs), Market Reaction and Financial Performance. Asian Academy of Management Journal of Accounting and Finance, 5(1), 117-138. 
Parkin, M. (2005). Economics. Seventh edition, Singapore, Addison-Wesley.

Pendleton, A. \& Andrew, R. (2010). Employee Stock Ownership, Involvement, and Productivity: An Interaction Based Approach. Industrial and Labor Relations Review, 64(1), 23-35.

Sesil, J. C. \& Maya, K. K. (2005). The Impact of Broad-Based Stock Options on Firm Performance: Does Size Matter? A quick view. Working paper series in human resource management. Retrieved 4 September fromhttp://chrs.rutgers.edu/pub_documents/Article\%2023\%20all.pdf .

Securities Commission Malaysia. Retrieved 24 August 2011 from http://www.sc.com.my.

Sengupta S., Whitfield, K. \& McNabb, B. (2007). Employee share ownership and performance: golden path or golden handcuffs? International Journal of Human Resource Management, 18(8), 1507-1538.

Soon, K. H. (2001). Employee Stock Options: Why Issue Them? Academic Exercise. University of Singapore. Business Section, The Star Newspaper, Saturday, $2^{\text {nd }}$ July 2011.

Tai, C. F. (2000). The Impact of Employee Stock Options on Firm Performance. Academic Exercise. National University of Singapore.

Yeo, G., Chen, S. S., Wai, H. K. \& Cheng-few, L. (1999). Effects of Executive Stock Options on Shareholder Wealth and Firm Performance: The Singapore Evidence. The Financial Review, 34, 1-20.

$\mathrm{Yu}$, P. L. (2008). Broad-based stock options program and firm productivity. Unpublished Ph.D dissertation. The State University of New York at Buffalo. 